\title{
Middle School Transition and Body Weight Outcomes: Evidence from Arkansas Public Schoolchildren
}

\section{Di Zeng ${ }^{1,{ }^{*}}$, Michael R. Thomsen ${ }^{1}$, Rodolfo M. Nayga Jr. ${ }^{1,2,3}$, Heather L. Rouse ${ }^{4,5}$}

${ }^{1}$ Department of Agricultural Economics and Agribusiness, University of Arkansas

${ }^{2}$ Norwegian Institute of Bioeconomy Research

${ }^{3}$ Korea University

${ }^{4}$ Health Policy Research, Arkansas Center for Health Improvement

${ }^{5}$ University of Arkansas for Medical Sciences

*Corresponding author.

Tel: 1-479-575-2256. Fax: 1-479-575-5306. Email: dizeng@uark.edu

Address: 217 Agricultural Building, University of Arkansas, Fayetteville, AR 72703, United States. 
Abstract: There is evidence that middle school transition adversely affects educational and psychological outcomes of pre-teen children, but little is known about the impacts of middle school transition on other aspects of health. In this article, we estimate the impact of middle school transition on the body mass index (BMI) of public schoolchildren in Arkansas, United States. Using an instrumental variable approach, we find that middle school transition in grade 6 led to a moderate decrease of 0.04 standard deviations in BMI z-scores for all students. Analysis by subsample indicated that this result was driven by boys (0.06-0.07 standard deviations) and especially by non-minority boys ( 0.09 standard deviations). We speculate that the changing levels of physical activities associated with middle school transition provide the most reasonable explanation for this result.

Key Words: middle school transition, weight, children, body mass index, Arkansas 


\section{Introduction}

High rates of obesity among young people constitute a serious public health issue in the United States. Nearly one in five adolescents is obese (Ogden et al., 2014). Schools are a prominent feature in the lives of youth that can contribute to obesity prevention (Carter, 2002; Belfield and Kelly, 2013). Foods consumed at school are an important source of children's overall dietary intake (Mancino et al., 2010), and the food environment in and around school can affect the body weight of children (Alviola et al., 2014; Kapinos et al., 2014). Schools also provide structured and unstructured opportunities for physical activity along with health and nutrition education. Finally, schools are the primary place peer effects on obesity may occur (Yakusheva et al., 2011; Gwozdz et al., 2015). For these reasons, the school environment is of interest in the design of policy interventions to address and prevent high rates of childhood obesity (Bauhoff, 2014; Mora et al., 2015).

In the United States, the provision of public education is a function that is controlled primarily by state and local governments. As a result, there are differences in how public schools are configured across locales. Early elementary or primary school grades, kindergarten (K) through $4^{\text {th }}$ grades, are almost invariably spent in elementary schools. Secondary school grades, $9^{\text {th }}$ or $10^{\text {th }}$ through $12^{\text {th }}$ grades, are spent in high schools. Various arrangements are used to house students in intermediate grades. In some locales, children transition out of elementary school and into a middle school as they enter $5^{\text {th }}$ or $6^{\text {th }}$ grade. In others, children remain in elementary schools for $5^{\text {th }}$ or $6^{\text {th }}$ grades. In this article, we investigate whether differences between elementary schools and middle schools affect the body weight of schoolchildren. Specifically, we compare the body mass index (BMI) z-scores of children who transition out of elementary schools and into middle schools during grades 5 and 6 to children that spend grades 5 
and 6 in an elementary school setting. Our methods parallel earlier studies that have compared academic outcomes of schoolchildren enrolled in elementary schools to those enrolled in middle schools (Rockoff and Lockwood, 2010; Schwerdt and West, 2013).

The question of whether one school format is more or less obesogenic than another is relevant to public education policy pertaining to the middle-school movement. In the United States, enrollments in middle schools grew during the last half of the $20^{\text {th }}$ century and accounted for just over half of the $6^{\text {th }}$ graders by 2001 (Bedard and Do, 2005). However, there is emerging evidence that the transition into middle school leads to lower academic achievement (Alspaugh, 1998; Bedard and Do, 2005; Byrnes and Ruby, 2007; Rockoff and Lockwood, 2010; Schwerdt and West, 2013) and discipline problems (Cook et al., 2008). In fact, there have been recent calls to abandon middle schools or reevaluate them in favor of alternative configurations (Pardini, 2002; Elovitz, 2007; Jacob and Rockoff, 2011). Given high rates of childhood obesity, the question of whether middle schools and elementary schools contribute differently to excess weight gain provides an additional and important dimension to the debate on the efficacy of middle schools.

There are several differences between middle school environments and elementary school environments that may affect excess body weight. First, there is evidence that middle schools present students with greater access to low-nutrition and energy-dense foods in comparison to elementary schools. Data summarized in Breifel et al. (2009) indicate that vending machines exist in over 90 percent of middle schools but only 25 percent of elementary schools. The availability of less healthy foods in vending machines is associated with higher BMI z-scores (Fox et al., 2009a). A la carte foods and beverages, including those that are energy dense and of low nutritional value, are also more prevalent among middle schools in comparison to 
elementary schools (Briefel et al., 2009). Finally, contracts with beverage companies are of more economic importance among middle schools. The US Government Accountability Office (2005) estimated that 45 percent of middle schools earned at least $\$ 25,000$ dollars per year from beverage contracts and 27 percent earned at least $\$ 50,000$ per year. In contrast, the corresponding percentages for elementary schools were 11 percent and 2 percent, respectively. There is some evidence that beverage contracts translate into higher consumption of sweetened beverages at school. For example, the percentage of children consuming beverages other than milk or 100 percent juice in middle school is 58 percent compared to only 18 percent among elementary schoolchildren (Fox et al., 2009b).

On the other hand, middle schools provide more physical activities than elementary schools (Simons-Morton et al., 1994; Tompkins et al., 2004), and so may do a better job of helping pre-teens develop healthy habits and behaviors towards physical activity. As a general rule, middle schools are larger than elementary schools and span a narrower age range. For this reason, middle schools may be better able to justify expenditures in facilities and equipment that lead to better physical education experiences at school and translate into healthier exercise behaviors through adolescence. One study found that middle schools were more likely to make both indoor and outdoor recreational facilities available to students outside of normal school hours (Tompkins et al., 2004), and there is evidence that it is cost-effective for middle schools to enter into shared use agreements for after-school programs that encourage physical activity (Kanters et al., 2014). Middle school students also generally dress for gym classes (Kahan and Graham, 2013). Changing out of street clothes into clothing more suitable for exercise may promote more vigorous physical activity during formal physical education classes. For these 
reasons, middle schools are in a better position to provide organized intramural or interscholastic sports programs for students, which may be effective at increasing physical activity.

Finally, the social environment confronting pre-teens in middle school may differ from those in elementary school in ways that affect weight gain as well as academic achievement. Children that enter middle school are confronted with older peers and enter an environment where adolescent pressures to conform to socially idealized body norms may be more prominent than those confronting similarly aged children in an elementary school setting (Hasenblas et al., 2013). This may affect attitudes towards diet and exercise. There is also concern that transition to middle school environments stresses pre-teens (Hellem 1990) and this may place students at greater risk of gaining excess weight. Stress may be one factor that contributes to obesity in late childhood or early adolescence (Wilson and Sato, 2013).

While there are multiple mechanisms by which middle schools and elementary schools may be more or less obesogenic, our emphasis in this article is to determine whether these differences, on balance, translate into differences in body weight among pre-teen schoolchildren and whether these differences persist into early adolescence. To do this, we use a unique panel dataset of measured, not self-reported, BMI z-scores covering the population of schoolchildren in Arkansas, United States. The state of Arkansas is an interesting case to study since it has one of the highest childhood obesity rates in the United States, and there is ample diversity across the state's $300+$ school districts in approaches to housing students in grade 5 and 6 . We follow the methods used in Rockoff and Lockwood (2010) and Schwerdt and West (2013) but use these methods to assess differences in body weight instead of differences in educational achievement. Specifically, we use an instrumental variable estimation to assess the causal impacts on students' BMI, where the instruments are based on the terminal grades of the school that children attended 
as $3^{\text {rd }}$ graders. Our identification assumption is that there are no unobservable factors in the $3^{\text {rd }}$ grade that can lead to possible changes in the student's BMI at exactly the same time he or she enters middle school.

Our primary finding is that transitioning into a middle school in grade 6 may be beneficial in terms of lowering body weight. This finding is largely driven by male students and non-Hispanic white (non-minority) students. Moreover, we provide evidence that for nonminority boys, reduced body weights attributable to the middle school transition may persist through grade 8 .

The article proceeds as follows. Section 2 describes the Arkansas BMI data upon which our analysis is based. Sections 3 and 4 present our methodology, main findings, and additional results from multiple robustness check procedures. Section 5 discusses physical exercise as the most likely mechanism that may explain this finding. Section 6 concludes.

\section{Data}

Our study uses a panel data set covering the population of public schoolchildren in Arkansas, United States. These data are from annual BMI screenings conducted in partial fulfillment of the requirements of Act 1220, passed in 2003 by the Arkansas General Assembly to combat high rates of childhood obesity. With passage of this act, Arkansas became the first state to systematically assess children for healthy body weight. The screening process is conducted by trained personnel within the public schools and follows statewide protocols to ensure uniformity in measurement procedures and equipment. Data from the screening process are maintained by the Arkansas Center for Health Improvement (ACHI) and our analyses of these data took place on a secured computer at ACHI's premises in Little Rock, Arkansas. The overwhelming 
majority of public schools (94 to 99 percent) participate in the screening program and BMI measures are obtained from at least 82 percent of target students in each year (Justus et al., 2007). BMI is computed as a ratio ([weight in pounds/(height in inches) $\left.)^{2}\right] \times 703$ ), and is then converted to age and gender-specific z-scores according to the guidelines provided by the Centers for Disease Control and Prevention (CDC, 2015). The use of BMI z-scores rather than direct BMI values helps to disentangle possible confounding factors, such as age-related adiposity rebound, puberty, and differences in growth trajectories by gender.

During the period covered by our study, there was a change in frequency of BMI screenings. In the 2003/2004 through 2006/2007 academic years, all schoolchildren were targeted for annual screenings. However, beginning with the 2007/2008 academic year, the state switched to screening children biennially with children in even-numbered grades from kindergarten through grade 10 being targeted for screenings each year. Our study uses a subset of the Arkansas childhood BMI database, which provides BMI measures of schoolchildren during seven academic years (2003/2004 through 2009/2010). Table 1 presents the available cohorts through which it is possible to follow children's BMI through time in this dataset. In addition to BMI z-score, these data provide information on the child's gender, age (in months), race, and whether the child qualified for free or reduced price school lunches.

Most elementary schools in Arkansas follow a K-4, K-5 and K-6 configuration. Together these three elementary school configurations account for $72.26 \%$ of $3^{\text {rd }}$ graders in our sample. Other school types are also observed on a less frequent basis, mainly K-3, 3-5 and 3-6 schools. ${ }^{1}$ In our primary investigation, we exclude schools with these less common grade

\footnotetext{
${ }^{1}$ A K-4 elementary school provides education to students from kindergarten through grade 4 . Similarly, a 3-5 school covers the grades from 3 to 5. In our dataset, annual enrollments in K-4, K-5 and K-6 schools average 15,575, 25,195 , and 21,138 students, respectively. Across these three major types of elementary school, minority students account for $31.38 \%, 32.53 \%$ and $29.96 \%$ of all students, respectively.
} 
configurations because frequent changes in school may confound the impact of a transition to middle school. That said, as a robustness check, we include these schools in a follow-up estimation. There are very few K-7 or K-8 schools in our sample and virtually all children were in middle school by grade 7. This minimizes concerns over missing grade 7 BMI measurements in later years of the study period, after the transition to even-grade-only BMI measurement.

Given these school configurations, we compare children who transitioned into middle schools in either grade 5 or 6 with those who stayed in elementary schools for these grades. We focus on students from grade 3 to grade 8 , and therefore narrow our data to cohorts III and IV in Table 1. We further exclude a very small portion of students who repeated or skipped grades and require that each student be observed five times during the study period. Our resulting panel is balanced in the sense that all children are observed in grades 3, 4, 5, 6 and 8 .

Consistent with Rockoff and Lockwood (2010) and Schwerdt and West (2013), we employ an instrumental variable technique to investigate the impact of middle school transition. Specifically, we instrument the year of transition into middle school with the highest grade of the school where the child spent grade 3 . The rationale for this strategy is that the grade of middle school transition is highly correlated with the highest grade available in elementary school. The three main elementary school configurations, $\mathrm{K}-4, \mathrm{~K}-5$, and $\mathrm{K}-6$ are common throughout the state, but as shown in Table 2, the BMI z-scores were slightly higher for students who transitioned to middle school in a higher grade. The proportion of minority students was also higher among those transitioning to middle school in grade $6 .^{2}$ Possible differences between minority and non-minority students are examined in detail following the main estimation.

\footnotetext{
${ }^{2}$ Non-minority students are defined as non-Hispanic white students. Minority students are the complement to this set and are comprised predominantly of African American and Hispanic children. Children from other racial/ethnic groups were not represented in our data in numbers sufficient to permit analyses by subgroup.
} 


\section{Empirical analysis}

While our identification strategy parallels that of Rockoff and Lockwood (2010) and Schwerdt and West (2013), our outcome variable is the child's BMI z-score. Specifically, we consider the BMI of student $i$ in grade $g$ as a function of student fixed effects $\alpha i$, grade fixed effects $\delta g$, a set of dummy indicators $M i g G$ indicating whether student $i$ entered middle school in grade $G$, a vector of controls, $\mathrm{Xig}$, and an idiosyncratic error eig that includes unobserved time-varying individual characteristics and other factors influencing the BMI outcome of student $i$ and the remaining measurement error. This is presented in Eq. (1):

$$
B M I i g=\alpha i+\delta g+\beta g G M i g G+\gamma X i g+\epsilon i g
$$

The coefficient $\beta g G$ is allowed to vary across grades to detect relative differences in BMI outcomes between students who entered middle schools and those who did not both before and after the transition to middle school. This is accomplished by interacting the grade dummies and school transition indicators. One issue is that students who enter middle school later experience changes in BMI in earlier grades, which could confound the estimated impact of middle school transition. Another is that we would like to know whether the impact continues and/or evolves over time after middle school transition. The coefficient vector $\beta g G$ enables us to detect both trends and disentangle possible confounding impacts to assess the credibility of the estimate.

We use a two-stage least squares (2SLS) estimation procedure in which we instrument for middle school transition in grade 5 or 6 using the terminal grade of the school that a student attended in grade 3. To be specific, we instrument for middle school transition in grade 5 with a binary indicator for whether the school a student attended in grade 3 ended at grade 4 , and 
instrument for middle school transition in grade 6 with a binary indicator for whether the school he or she attended in grade 3 ended at grade 5 . The choice of grade 3 rather than other grades in determining the terminal grade of the school a student attended earlier is not arbitrary. First, as shown in Table 1, a choice of an even lower grade would reduce the number of cohorts available for the analysis. Second, the choice of a higher grade would limit variation in the instrument. For these two reasons, basing instruments on the terminal grade of the child's school in grade 3 was selected as the best available solution.

The first-stage regressions suggest that these instruments are strong predictors of middle school transition (see Table A.1 in the Appendix). The coefficient estimates are about 0.7 to 0.8 and are highly significant. Moreover, $81.8 \%$ of $3^{\text {rd }}$ graders in a school with a terminal grade of 4 enter middle school in grade 5 , while $68.5 \%$ of $3^{\text {rd }}$ graders in a school with the terminal grade of 5 enter middle school in grade 6.

The BMI impacts of middle school transition of these groups could, though not necessarily, differ from those among the overall population. Specifically, according to our empirical model, it is the local average treatment effect of the subset of those transitioning as expected given the type of school in grade 3 that our instrumental variable estimation would identify (Imbens and Angrist, 1994). For example, a residential move to a school district with different grade configurations could alter the timing of middle school entry from what would have been expected given the structure of the child's $3^{\text {rd }}$ grade school. In fact, residential moves account for the majority of such variation. Forty-four percent of students in our data moved residences during the period of study, but more than a half of these students experienced similar grade configurations before and after the move, which would largely downscale any possible differences between local and population average treatment effects. In fact, the local average 
treatment effect to be identified in our study is felt by the majority, and is of considerable policy interest in Arkansas where many people live in rural areas, and therefore middle school transition is largely determined by grade configuration in the localities.

We estimate two regression models, with or without the vector of covariates, Xig, respectively. ${ }^{3}$ Empirically, Xig includes the student's age and a dummy indicator of free school lunch status for student $i$ in grade $g$, as well as school characteristics, namely the proportions of female students and minority students. Robust standard errors are employed. In addition to the 2SLS procedure, we also estimate each model using OLS for comparison purposes.

Our baseline results are reported in Table 3. The instrumental variable models are appropriately identified. The OLS and 2SLS estimates are similar as are estimates from models with and without the additional covariates. It is seen that the grade 6 interaction term with those students transitioning to middle school indicates a decrease of 0.04 standard deviations in the BMI z-score. In the 2SLS estimates, no other grade interaction terms are significant. Specifically and interestingly, there is no impact for students who entered middle school in grade 5, which may suggest the possibility of systematic differences between either the students entering middle school in different grades, or characteristics of these two grades.

We next estimate these models using subsamples by gender. Table 4 presents the 2SLS estimates. Again, OLS estimates (not reported) are similar. The conclusion from Table 5 is that boys primarily account for the reduction in BMI z-score that accompanies the transition to middle school in grade 6. A 0.06-0.07 reduction in BMI z-score is observed for boys, while

\footnotetext{
${ }^{3}$ The dependent variable in both models is the BMI z-score. Alternatively, we also estimated models with binary outcome indicators, including overweight (BMI z-score above the 85 percentile) and obesity (BMI z-score above the 95 percentile). However, we see no significant weight impacts of middle school transition using either indicator. This is not surprising given that the estimates in terms of BMI z-score are small (discussed in detail below). These alternative results for overweight and obesity status are therefore not reported as they add little to the policy information.
} 
there is no significant impact for girls. This result implies that middle school transition may affect boys and girls through different mechanisms or that the same mechanisms yield genderspecific impacts.

Table 5 further reports the estimated impacts of middle school transitions on BMI zscores for different student sub-samples by gender and minority status. ${ }^{4}$ As noted above, minority students accounted for a higher proportion of enrollments in schools that had a transition in grade 6. Across all subsamples, the 2SLS estimates with or without covariates are very close, and only the estimates from the models with covariates are reported.

There are noteworthy differences between the minority and non-minority subsamples. Non-minority students show a 0.07 BMI z-score reduction with middle school transitions in grade 6 , and such impact persists through grade 8 . Consistent with the above results, the impact for boys is moderately larger in absolute value (0.09) than that for girls $(0.06)$. Conversely, there is little evidence that middle school transition affects the BMI z-score of minority students. Although minority boys may have experienced some reduction of BMI z-score as a result of the transition, such impact is much smaller in magnitude in comparison to non-minority students and is only marginally significant. In sum, Table 5 provides evidence that it is the non-minority subsample that drives the full-sample estimates of BMI reductions from middle school transitions in grade 6.

\section{Robustness checks}

We now address several concerns that may be a threat to our main results discussed above. First, it may be the case that the estimates reflect alternative mechanisms that had nothing to do with

\footnotetext{
${ }^{4}$ Further analysis was performed by further distinguishing the impacts between African Americans and Hispanics. However, there is no meaningful difference in the results between these two major minority groups, and the impact estimates are smaller and insignificant. These results are therefore not reported in detail in the interest of space.
} 
the middle school transition. For example, frequent changes of residence and/or school, may lead to BMI z-score decreases in grade 6 especially among boys. Such changes may be driven by average test scores, class size, perceived level of competitiveness, and racial structure (e.g. Glazeman, 1998; Bosetti, 2004; Hastings and Weinstein, 2008). It is also possible that such changes result from preferences for school health environments. Changes in school or residence might reduce the availability of social and personal support (Bowlby, 1969; Brown and Harris, 1978; Birleson, 1981), which might also affect body weight. To investigate whether the estimates reflect mechanisms other than school transition, we carry out two robustness checks. First, we homogenize our sample to include only non-movers, namely those students who had the same address at each point during the study period. ${ }^{5}$ Second, we alternatively homogenize our sample to include students who changed school only once from elementary school into middle school (one-time switchers). These procedures are further implemented using subsamples by gender and minority status. Estimated results are presented in Tables A.2 and A.3 in the Appendix. These estimates are very similar to those reported above, which provides evidence that the mechanisms behind the estimated changes in z-score are, in fact, linked to the transition to middle school.

A second threat to the validity of our estimates is whether unobserved heterogeneity across school districts affects students' BMI in grade 6. Such heterogeneity may be important because school policies vary across school districts (Schwartz et al., 2012), which may then influence the availability of low-nutrient and energy-dense foods offered in schools (Kubik et al., 2011), and food consumption decisions of students (Cradock et al., 2011). Hence, any

\footnotetext{
${ }^{5}$ Admittedly, residential location decisions and the associated school district are based on family choices. Therefore, the robustness test of estimating from samples containing only non-movers may not totally rule out endogeneity resulting from these past decisions. This is another reason to assess robustness of the estimates to the inclusion/exclusion of school-district effects as we do below.
} 
systematic linkage between these policies and school grade configuration in a geographical context would challenge our results. To address this issue, we re-estimate the model with controls for school-district fixed effects which aim to control for time-invariant unobserved heterogeneity at this level. As reported in the Appendix (Table A.4), estimates and distributional patterns are similar to those reported above when the models include school-district fixed effects, lending further credence to our main results.

One minor issue is further addressed. There is a possibility that our results are biased due to exclusion of less common types of schools that students attended in grade 3, mainly K-3, 3-5 and 3-6 schools. To assess this, we included these additional schools and re-estimated the models. Estimates are reported in Table A.5 in the Appendix. We see no meaningful changes to the results.

\section{Discussion}

Our primary finding is that a transition into middle schools in grade 6 may have beneficial impacts on preteen children in terms of healthier body weight. What benefits there are accrue primarily to boys and are most evident among the subsample of non-minority boys. It is useful to place the magnitude of our estimates into context. For a $6^{\text {th }}$ grade boy of 12 years, the reduction in BMI z-score attributable to the middle school transition is estimated to be as large as 0.09 standard deviations. A boy 4 feet and 11 inches in height with a weight of 97.5 pounds would have a BMI z-score near our sample average of 0.674 . For this boy, a reduction in z-score of 0.09 standard deviations would be equivalent to a reduction in body weight of roughly 1.5 pounds. In short, the impacts we estimate are not large in terms of percentage of body weight. 
That said, among the sample of non-minority boys there is evidence that these reductions, although small, persist through grade 8 .

Going into this study, we did not have strong a priori hypotheses on the sign of the middle-school transition impact. As outlined in the introductory material to this article, there is evidence that middle school students confront food environments where low-nutrition and energy-dense foods are more common, which may translate into consumption of more calories in comparison to similarly-aged children in elementary schools. On the other hand, there is evidence that middle school environments may be more conducive to physical activity. Finally, the differences of being in the adolescent-oriented environment of a middle school may affect attitudes and behaviors in ways that also affect excess weight gain.

While our methods do not address these underlying mechanisms directly, our findings are in accordance with an argument that physical activity is the dominant mechanism explaining differences in BMI attributable to the middle school transition. This is consistent with the earlier studies showing that middle school students have higher levels of physical activities than elementary school students (e.g. Simons-Morton et al., 1994; McKenzie et al., 2000) and is further supported by the fact that the benefits of middle school transition fall disproportionately on boys. There is evidence that middle-school aged girls are less physically active than boys (Robbins et al., 2009; Rusby et al., 2014), and features of the middle school environment may advantage boys in a way that accelerates or amplifies these gender differences. Specifically, Kanters et al. (2014) find that middle school boys are more likely than girls to participate in intramural sports. As argued above, the ability to provide structured programs such as intramural sports are one area where middle schools will have a clear programming advantage over elementary schools. Others have noted that middle-school physical education curricula are 
tailored to male strengths and interests (Olafson, 2002), and this may lead to lower participation among girls. Similarly, girls may also seek to avoid associations with aggressiveness and athleticism (Vu et al., 2006). For these reasons, it is not surprising that Kahan and Graham (2013) report a higher frequency of "non-suiting" among girls in a middle school physical education program. ${ }^{6}$ Finally, the impacts of exercise may also differ between genders. Govinden et al. (2013) find stronger evidence of an association between exercise and obesity among middle school boys in comparison to girls.

One puzzling finding is that there was no beneficial impact on the weight of children of either gender who transitioned to middle school in grade 5. It is plausible that programs in middle schools with younger children differ from those with older children in ways that affect body weight, although gender differences may also be behind this finding. Differences in physical activity between boys and girls also grow wider with age (Pratt et al., 1999; McKenzie et al., 2000, Kimm et al., 2002). In fact, Hoelscher et al. (2009) found that in grade 4, boys and girls had similar levels of physical activity. Given this, it may be that younger boys benefit less from the physical activity environments in middle schools. In other words, what middle schools offer by way of opportunities for physical activity beyond what can be found in elementary schools could be better aligned with the needs of older boys or could appeal more to older boys. Since the impact we see is driven primarily by boys, this may be one factor that contributes to the lack of an impact among children making an earlier transition to middle school.

Finally, we find the strongest evidence of the impact among non-minority children. There is evidence that African American and Hispanic students tend to have lower levels of physical activity (e.g. Pratt et al., 1999; Gordon-Larsen et al., 2000, 2004; Johnston et al., 2007). Together, these two groups comprise the vast majority of children in the minority subsample. To

\footnotetext{
${ }^{6}$ Non-suiting refers to a student's failure to change into gym clothes for the physical education class.
} 
the extent that middle schools provide more structured opportunities for physical activity outside of the normal school hours, it is possible that children from disadvantaged socioeconomic backgrounds lack resources to participate (or to participate fully) in these programs. This would be the case if the child's family was unable to provide transportation to or from after-school sporting events or practices. In some cases, participation may also involve personal athletic equipment that may be infeasible given family resource constraints. However, there is weak evidence that minority boys also experienced some reduction of BMI z-scores as a result of a $6^{\text {th }}$ grade transition to middle school. Further investigations are needed with more informative data to address such disparities.

\section{Concluding remarks}

We investigate the impact of middle school transition on body weight using a statewide panel dataset from Arkansas, United States. Overall, middle school entrance in grade 6 led to a small decrease in BMI z-scores. This impact was largely driven by boys, who experienced an average BMI z-score decrease and was insignificant for girls. Interestingly, there was no impact of middle school transition in grade 5 , which may be due to systematic differences in programming between middle schools serving slightly older and younger children. It could also be that slightly older children respond differently to middle school environments and it is worth noting that many children will be experiencing the onset of puberty around this age. Estimates from minority and non-minority subsamples further show that the largest BMI z-score reductions were among the non-minority students. There was little impact among minority students.

We argue that differences in exercise environments between elementary and middle schools is the most plausible explanation of the beneficial impact of middle school transition on 
the body weight of non-minority boys. The public health literature offers strong evidence that, 1) middle school students have higher levels of physical activities than elementary students; 2) middle school girls tend to be less active than boys; and 3) minority students tend to be less physically active.

Given the high childhood obesity rates in the United States, our results suggest that middle school transition might have desirable impacts on students' body weight. However, the magnitudes are small and the benefits may not be equally shared among girls or minorities. Thus, we do not see these results as presenting a serious challenge to reforms aimed at recombining elementary and middle schools (Pardini, 2002; Reising, 2002; Hough, 2005). Rather, our findings provide insight into one more dimension of the childhood obesity problem and suggest that it may be worth further inquiry into the underlying mechanisms that may be behind the beneficial effects of middle school transition. For example, if exercise truly is the dominant mechanism, there may be opportunities to improve physical activities targeting $6^{\text {th }}$ graders in elementary school environments or enhance the design of programs to encourage participation across students regardless of gender or minority status.

In addition, there are limitations to our study beyond our inability to speak conclusively to the mechanism underlying the middle school transition effect. One is that we do not have a precise measure of household income for the children in our sample and rely instead on whether children qualify for free or reduced price school meals. School meal status is determined by household income but we acknowledge that it is an imprecise measure and that household income may be especially meaningful for minority groups with higher obesity rates, possibly due to low socioeconomic status (Wang and Beydoun, 2007). Another and related limitation is that excess weight gain depends on a myriad of individual and environmental factors that cannot be 
completely controlled in a population-based studies such as ours. Despite these limitations, we contend that the current study still provides some robust evidence regarding the moderate but beneficial impact of middle school transition on preventing excess weight gain during early adolescence. 


\section{Acknowledgements}

This work was funded by the Agriculture and Food Research Initiative Competitive Grant No. 2011-68001-30014 from the USDA National Institute of Food and Agriculture. This work is also partly supported by the Arkansas Biosciences Institute and the National Research Foundation of Korea (NRF-2014S1A3A2044459). The authors wish to thank Editor Inas Rashad Kelly and three anonymous reviewers for valuable comments. The views are solely from the authors and do not necessarily reflect the views of either the donor or the authors' institutions. The usual disclaimer applies. 


\section{References}

Alspaugh, J.W. 1998. Achievement loss associated with the transition to middle school and high school. Journal of Educational Research 92(1), 20-25.

Alviola, P.A., IV, Nayga, R.M., Jr., Thomsen, M.R., Danforth, D., Smartt, J. The effect of fastfood restaurants on childhood obesity: A school level analysis. Economics \& Human Biology 12: 110-119.

Bauhoff, S. 2014. The effect of school district nutrition policies on dietary intake and overweight: A synthetic control approach. Economics \& Human Biology 12, 45-55.

Bedard, K., Do, C. 2005. Are middle schools more effective? The impact of school structure on student outcomes. Journal of Human Resources 40(3), 660-682.

Belfield, C.R., Kelly, I.R. 2013. Early education and health outcomes of a 2001 U.S. Birth Cohort. Economics \& Human Biology 11(3), 310-325.

Birleson, P. 1981. The validity of depressive disorder in childhood and the development of a self-rating scale: a research report. Journal of Child Psychology and Psychiatry 22(1), 73-88.

Bosetti, L. 2004. Determinants of school choice: understanding how parents choose elementary schools in Alberta. Journal of Education Policy 19(4): 387-405.

Bowlby, J. 1969. Attachment and Loss. London: Hogarth Press.

Briefel, R.R., Crepinsek, M.K., Cabili, C., Wilson, A., Gleason, P.M. 2009. School food environments and practices affect dietary behaviors of US public school children. Journal of the American Dietetic Association 109(2), S91-S107. 
Brown, G.W., Harris, T. 1978. Social Origins of Depression: A Study of Depression in Women. London: Tavistock.

Byrnes, V., Ruby, A. 2007. Comparing achievement between K-8 and middle schools: a largescale empirical study. American Journal of Education 114(1), 101-135.

Carter, R.C. 2002. The impact of public schools on childhood obesity. Journal of the American Medical Association 288(17), 2180.

Centers for Disease Control and Prevention (CDC). 2015. About BMI for Children and Teens. http://www.cdc.gov/healthyweight/assessing/bmi/childrens bmi/about childrens bmi.ht $\underline{\mathrm{ml}}$

Cook, P.J., MacCoun, R., Muschkin, C., Vigdor, J. 2008. The negative impacts of starting middle school in sixth grade. Journal of Policy Analysis and Management 27(1), 104121.

Cradock, A.L., McHugh, A., Mont-Ferguson, H., Grant, L., Barrett, J.L., Gortmaker, S.L., Wang, C. 2011. Effect of school district policy change on consumption of sugar-sweetened beverages among high school students, Boston, Massachusetts, 2004-2006. Preventing Chronic Disease 8(4), A74.

Elovitz, L.H. 2007. Middleschoolosaurus Rex: Is the Middle School Becoming Extinct? Principal Leadership 7(7), 26-30.

Fox, M.K., Dodd, A.H., Wilson, A., Gleason, P.M. 2009a. Association between school food environment and practices and body mass index of US public school children. Journal of the American Dietetic Association 109(2), S108-S117. 
Fox, M.K., Gordon, A., Nogales, R., Wilson, A. 2009b. Availability and consumption of competitive foods in US public schools. Journal of the American Dietetic Association 109(2), S57-S66.

Glazerman, S.M. 1998. School quality and social stratification: the determinants and consequences of parental school choice. Paper presented at the Annual Meeting of the American Educational Research Association, April 13-17, 1998, San Diego, CA.

Gordon-Larsen, P., McMurray, R.G., Popkin, B.M. 2000. Determinants of adolescent physical activity and inactivity patterns. Pediatrics 105(6), e83.

Gordon-Larsen, P., Nelson, M.C., Popkin, B.M. 2004. Longitudinal physical activity and sedentary behavior trends: adolescence to adulthood. American Journal of Preventive Medicine 27(4), 277-283.

Govindan, M., Gurm, R., Mohan, S., Kline-Rogers, E., Corriveau, N., Goldberg, C., DuRusselWeston, J., Eagle, K.A., Jackson, E.A. 2013. Gender differences in physiologic markers and health behaviors associated with childhood obesity. Pediatrics 132(3), 468-474.

Gwozdz, W., Sousa-Poza, A., Reisch, L.A., Bammann, K., Eiben, G., Kourides, Y., Kovács, É., Lauria, F., Konstabel, K., Santaliestra-Pasias, A.M., Vyncke, K., Pigeot, I. 2015. Peer effects on obesity in a sample of European children. Economics \& Human Biology 18, $139-152$.

Hastings, J.S., Weinstein, J.M. 2008. Information, school choice, and academic achievement: evidence from two experiments. The Quarterly Journal of Economics 123(4): 1373-1414.

Hausenblas, H.A., Downs, D.S., Fleming, D.S., Connaughton, D.P. 2013. Body image in middle school children. Eating and Weight Disorders - Studies on Anorexia, Bulimia and Obesity 7(3), 244-248. 
Hellem, D.W. 1990. Sixth grade transition groups: An approach to primary prevention. Journal of Primary Prevention 10(4), 303-311.

Hoelscher, D.M., Barroso, C., Springer, A., Castrucci, B., Keider, S.H. 2009. Prevalence of selfreported activity and sedentary behaviors among 4th-, 8th-, and 11th-grade Texas public schoolchildren: The school physical activity and nutrition study. Journal of Physical Activity and Health 6(5), 535-547.

Hough, D.L. 2005. The rise of the 'Elemiddle' school. School Administrator 62(3), 10-14.

Imbens, G.W., Angrist, J.D. 1994. Identification and the estimation of local average treatment effects. Econometrica 62(2), 467-475.

Jacob, B.A., Rockoff, J.E. 2011. Organizing schools to improve student achievement: start times grade configurations, and teacher assignments. The Hamilton Project Discussion Paper 2011-08, September.

Johnston, L.D., Delva, J., O’Malley, P.M. 2007. Sports participation and physical education in American secondary schools: current levels and racial/ethnic and socioeconomic disparities. American Journal of Preventive Medicine 33(4 Suppl.), S195-S208.

Justus, M.B., Ryan, K.W., Rockenbach, J., Katterapalli, C., Card-Higginson, P. 2007. Lessons learned while implementing a legislated school policy: body mass index assessments among Arkansas's public school students. Journal of School Health 77(10), 706-713.

Kahan, D., Graham, K. 2013. Quantitative analysis of students' reasons for nonsuiting and support of policy change at one urban middle school. Research Quarterly for Exercise and Sport 84(4), 512-521.

Kanters, M.A., Bocarro, J.N., Filardo, M., Edwards, M.B., McKenzie, T.L., Floyd, M.F. 2014. Shared use of school facilities with community organizations and afterschool physical 
activity program participation: A cost-benefit assessment. Journal of School Health 84(5), 302-309.

Kapinos, K.A., Yakusheva, O., Eisenberg, D. 2014. Obesogenic environmental influences on young adults: evidence from college dormitory assignments. Economics \& Human Biology 12, 98-109.

Kimm, S.Y.S., Glynn, N.W., Kriska, A.M., Barton, B.A., Kronsberg, S.S., Daniels, S.R., Crawford, P.B., Sabry, Z.I., Liu, K. 2002. Decline in physical activity in black girls and white girls during adolescence. The New England Journal of Medicine 347, 709-715.

Kubik, M.Y., Lytle, L.A., Farbakhsh, K. 2011. School and district wellness councils and availability of low-nutrient, energy-dense vending fare in Minnesota middle and high schools. Journal of the American Dietetic Association 111(1), 150-155.

Mancino, L., Todd, J.E., Guthrie, J. and Lin, B.-H. 2010. How Food Away from Home Affects Children's Diet Quality. USDA Economic Research Service, ERR-104, Washington DC.

McKenzie, T.L., Marshall, S.J., Sallis, J.F., Conway, T.L. 2000. Student activity levels, lesson context, and teacher behavior during middle school physical education. Research Quarterly for Exercise and Sport 71(3), 249-259.

Mora, T., Llargués, E., Recasens, A. 2015. Does health education affect BMI? Evidence from a school-based randomised-control trial. Economics \& Human Biology 17: 190-201.

Ogden, C., Carroll, M.D., Kit, B.K., Flegal, K.M. 2014. Prevalence of childhood and adult obesity in the United States, 2011-2012. Journal of the American Medical Association $311(8), 806-814$.

Olafson, L. 2002. I hate Phys. Ed.: Adolescent girls talk about physical education. Physical Educator 59(2), 67-74. 
Pardini, P. 2002. Revival of the K-8 school. School Administrator 59(3), 6-13.

Pratt, M., Macera, C.A., Blanton, C. 1999. Levels of physical activity and inactivity in children and adults in the United States: current evidence and research issues. Medicine \& Science in Sports \& Exercise 31(11 Suppl.), S526-S533.

Reising, B. 2002. Middle school models. Clearing House 76(2), 60-61.

Robbins, L.B., Sikorskii, A., Hamel, L.M., Wu, T.-Y., Wilbur, J. 2009. Gender comparisons of perceived benefits of and barriers to physical activity in middle school youth. Research in Nursing and Health 32(2), 163-176.

Rockoff, J.E., Lockwood, B.B. 2010. Stuck in the middle: impacts of grade configuration in public schools. Journal of Public Economics 94, 1051-1061.

Rusby, J.C., Westling, E., Crowley, R., Light, J.M. 2014. Psychosocial correlates of physical and sedentary activities in early adolescent youth. Health Education and Behavior 41(1), 4251.

Schwartz, M.B., Henderson, K.E., Falbe, J., Novak, S.A., Wharton, C.M., Long, M.W., O'Connell, M.L., Fiore, S.S. 2012. Strength and comprehensiveness of district school wellness policies predict policy implementation at the school level. Journal of School Health 82(6), 262-267.

Schwerdt, G., West, M.R. 2013. The impact of alternative grade configurations on student outcomes through middle school and high school. Journal of Public Economics 97, 308326.

Simons-Morton, B.G., Taylor, W.C., Snider, S.A., Huang, I.W., Fulton, J.E. 1994. Observed levels of elementary and middle school children's physical activity during physical education classes. Preventive Medicine 23(4), 437-441. 
Tompkins, N.O., Zizzi, S., Zedosky, L., Wright, J., Vitullo, E. 2004. School-based opportunities for physical activity in West Virginia public schools. Preventive Medicine 39(4), 834840.

US Government Accountability Office. 2005. School Meal Programs: Competitive Foods are Widely Available and Generate Substantial Revenues for Schools. Report to Congressional Requestors, GAO-05-563, Washington DC.

Vu, M.B., Murrie, D., Gonzalez, V., Jobe, J.B. 2006. Listening to girls and boys talk about girls' physical activity behaviors. Health Education \& Behavior 33(1), 81-96.

Wang, Y., Beydoun, M.A. 2007. The obesity epidemic in the United States - gender, age, socioeconomic, racial/ethnic, and geographic characteristics: a systematic review and meta-regression analysis. Epidemiologic Reviews 29(1), 6-28.

Wilson, S.M., Sato, A.F. 2014. Stress and pediatric obesity: what we know and where to go. Stress and Health 30(2), 91-102.

Yakusheva, O., Kapinos, K., Weiss, M. 2011. Peer effects and the Freshman 15: evidence from a natural experiment. Economics \& Human Biology 9(2), 119-132. 
Table 1. Cohort Structure and Data Availability by Grade: 2004-2010 ${ }^{1}$

\begin{tabular}{|c|c|c|c|c|c|c|c|}
\hline \multirow{2}{*}{ Cohort } & \multicolumn{7}{|c|}{ School grade attended by year } \\
\cline { 2 - 8 } & 2004 & 2005 & 2006 & 2007 & 2008 & 2009 & 2010 \\
\hline I & Kindergarten & 1 & 2 & 3 & 4 & & 6 \\
\hline II & 1 & 2 & 3 & 4 & & 6 & \\
\hline III & 2 & 3 & 4 & 5 & 6 & & 8 \\
\hline IV & 3 & 4 & 5 & 6 & & 8 & \\
\hline V & 4 & 5 & 6 & 7 & 8 & & 10 \\
\hline VI & 5 & 6 & 7 & 8 & & 10 & \\
\hline
\end{tabular}

${ }^{1}$ Each row reports progression of grades for which BMI z-scores are observed in the Arkansas BMI dataset and illustrates the transition to biennial measurement in even grades in 2008. Given that our central question is the effect of middle school transition, our analysis sample is drawn from cohorts III and IV. 
Table 2. Student Characteristics by Timing of Middle School Transition ${ }^{1,2}$

\begin{tabular}{|l|c|c|c|c|}
\hline & Full sample & $\begin{array}{c}\text { Grade 5 } \\
\text { transition }\end{array}$ & $\begin{array}{c}\text { Grade 6 } \\
\text { transition }\end{array}$ & $\begin{array}{c}\text { Other grades of } \\
\text { transition }\end{array}$ \\
\cline { 2 - 5 } & $\mathrm{n}=63,950$ & $\mathrm{n}=21,505$ & $\mathrm{n}=24,630$ & $\mathrm{n}=17,815$ \\
\hline BMI z-score & $0.674(1.063)$ & $0.654(1.067)$ & $0.672(1.058)$ & $0.701(1.062)$ \\
\hline Age in month & $133.42(20.99)$ & $133.25(25.97)$ & $133.25(20.98)$ & $133.86(18.21)$ \\
\hline Free lunch status (dummy) & $0.366(0.482)$ & $0.359(0.469)$ & $0.371(0.486)$ & $0.368(0.392)$ \\
\hline School female ratio & $0.487(0.042)$ & $0.488(0.035)$ & $0.491(0.044)$ & $0.480(0.041)$ \\
\hline School minority ratio & $0.320(0.373)$ & $0.268(0.291)$ & $0.416(0.427)$ & $0.250(0.313)$ \\
\hline
\end{tabular}

${ }^{1}$ Statistics are computed over the five years that each student was observed.

${ }^{2}$ Standard deviations are reported in parentheses.

${ }^{3}$ These students might have entered middle school in any grade higher than 6 , but mostly in grade 7 as very few elementary schools had their highest grades higher than 6 . 
Table 3. Full Sample Impact Estimates of Middle School Transition $(n=63,950)^{1}$

\begin{tabular}{|c|c|c|c|c|}
\hline & \multicolumn{2}{|c|}{ Without covariates } & \multicolumn{2}{|c|}{ With covariates } \\
\hline & OLS & 2SLS & OLS & 2SLS \\
\hline \multicolumn{5}{|l|}{ Transition in grade 5} \\
\hline Grade 4 interaction & $0.014(0.009)$ & $0.015(0.014)$ & $0.014(0.009)$ & $0.015(0.014)$ \\
\hline Grade 5 interaction & $0.011(0.010)$ & $0.012(0.013)$ & $0.012(0.010)$ & $0.013(0.014)$ \\
\hline Grade 6 interaction & $0.025(0.011)^{* *}$ & $0.005(0.014)$ & $0.026(0.012)^{* *}$ & $0.006(0.014)$ \\
\hline Grade 8 interaction & $0.003(0.014)$ & $-0.018(0.017)$ & $0.004(0.014)$ & $-0.016(0.017)$ \\
\hline \multicolumn{5}{|l|}{ Transition in grade 6} \\
\hline Grade 4 interaction & $-0.010(0.008)$ & $0.003(0.015)$ & $-0.010(0.009)$ & $0.003(0.015)$ \\
\hline Grade 5 interaction & $0.005(0.010)$ & $0.006(0.015)$ & $0.006(0.010)$ & $0.007(0.015)$ \\
\hline Grade 6 interaction & $-0.028(0.011)^{* *}$ & $-0.043(0.016)^{* * *}$ & $-0.027(0.011)^{* *}$ & $-0.043(0.016)^{* * *}$ \\
\hline Grade 8 interaction & $-0.022(0.013)^{*}$ & $-0.026(0.018)$ & $-0.021(0.013)$ & $-0.025(0.018)$ \\
\hline \multicolumn{5}{|l|}{ Grade dummies } \\
\hline Grade 4 & $0.009(0.006)$ & $0.004(0.010)$ & $0.026(0.012)^{* *}$ & $0.021(0.014)$ \\
\hline Grade 5 & $0.015(0.007)^{* *}$ & $0.014(0.010)$ & $0.044(0.023)^{* *}$ & $0.045(0.022)^{* * *}$ \\
\hline Grade 6 & $0.041(0.009)^{* *}$ & $0.053(0.010)^{* * *}$ & $0.078(0.033)^{* *}$ & $0.093(0.031)^{* * *}$ \\
\hline Grade 8 & $0.079(0.010)^{* *}$ & $0.087(0.012)^{* * *}$ & $0.117(0.054)^{* *}$ & $0.129(0.051)^{* *}$ \\
\hline \multicolumn{5}{|l|}{ Covariate estimates } \\
\hline Student age & & & $-0.006(0.003)^{* *}$ & $-0.006(0.002)^{* *}$ \\
\hline Free lunch status & & & $0.007(0.008)$ & $0.007(0.008)$ \\
\hline School minority ratio & & & $-0.041(0.032)$ & $-0.028(0.036)$ \\
\hline School female ratio & & & $0.053(0.051)$ & $0.054(0.047)$ \\
\hline Constant & $0.646(0.030)^{* * *}$ & & $1.028(0.188)^{* * *}$ & \\
\hline \multicolumn{5}{|l|}{ Test statistics } \\
\hline Overall $F$ & $17.75^{* * *}$ & $22.72^{* * *}$ & $10.71^{* * *}$ & $13.70^{* * *}$ \\
\hline $1^{\text {st }}$ stage $F$ significance & & All at $1 \%$ level & & All at $1 \%$ level \\
\hline Underidentification $^{2}$ & & $9811.90^{* * *}$ & & $7482.40^{* * *}$ \\
\hline Weak identification $^{3}$ & & 2732.33 & & 1987.73 \\
\hline
\end{tabular}


${ }^{3}$ Kleibergen-Paap (2006) rank Wald F statistic is reported 
Table 4. Gender-Specific 2SLS BMI Impact Estimates of Middle School Transition ${ }^{1}$

\begin{tabular}{|c|c|c|c|c|}
\hline \multirow[b]{2}{*}{ With covariates $^{2}$} & \multicolumn{2}{|c|}{$\begin{array}{c}\text { Boys } \\
(n=32,575)\end{array}$} & \multicolumn{2}{|c|}{$\begin{array}{c}\text { Girls } \\
(\mathrm{n}=31,375)\end{array}$} \\
\hline & No & Yes & No & Yes \\
\hline \multicolumn{5}{|c|}{ Transition in grade 5} \\
\hline $\begin{array}{l}\text { Grade } 4 \\
\text { interaction }\end{array}$ & $\begin{array}{c}0.018 \\
(0.020)\end{array}$ & $\begin{array}{c}0.018 \\
(0.020)\end{array}$ & $\begin{array}{c}0.012 \\
(0.019)\end{array}$ & $\begin{array}{c}0.012 \\
(0.020)\end{array}$ \\
\hline $\begin{array}{l}\text { Grade } 5 \\
\text { interaction }\end{array}$ & $\begin{array}{c}0.026 \\
(0.019)\end{array}$ & $\begin{array}{c}0.025 \\
(0.019)\end{array}$ & $\begin{array}{l}-0.001 \\
(0.019)\end{array}$ & $\begin{array}{c}0.002 \\
(0.019)\end{array}$ \\
\hline $\begin{array}{l}\text { Grade } 6 \\
\text { interaction }\end{array}$ & $\begin{array}{c}0.024 \\
(0.020)\end{array}$ & $\begin{array}{c}0.024 \\
(0.020)\end{array}$ & $\begin{array}{l}-0.015 \\
(0.019)\end{array}$ & $\begin{array}{l}-0.012 \\
(0.020)\end{array}$ \\
\hline $\begin{array}{l}\text { Grade } 8 \\
\text { interaction }\end{array}$ & $\begin{array}{l}-0.003 \\
(0.023)\end{array}$ & $\begin{array}{c}-0.002 \\
(0.023)\end{array}$ & $\begin{array}{l}-0.035 \\
(0.023)\end{array}$ & $\begin{array}{l}-0.032 \\
(0.023)\end{array}$ \\
\hline \multicolumn{5}{|c|}{ Transition in grade 6} \\
\hline $\begin{array}{l}\text { Grade } 4 \\
\text { interaction }\end{array}$ & $\begin{array}{c}0.009 \\
(0.022)\end{array}$ & $\begin{array}{c}0.004 \\
(0.022)\end{array}$ & $\begin{array}{l}-0.002 \\
(0.021)\end{array}$ & $\begin{array}{c}0.003 \\
(0.021)\end{array}$ \\
\hline $\begin{array}{l}\text { Grade } 5 \\
\text { interaction }\end{array}$ & $\begin{array}{l}-0.000 \\
(0.021)\end{array}$ & $\begin{array}{l}-0.004 \\
(0.021)\end{array}$ & $\begin{array}{c}0.014 \\
(0.021)\end{array}$ & $\begin{array}{c}0.020 \\
(0.021)\end{array}$ \\
\hline $\begin{array}{l}\text { Grade } 6 \\
\text { interaction }\end{array}$ & $\begin{array}{c}-0.063^{* * *} \\
(0.022)\end{array}$ & $\begin{array}{c}-0.068^{\text {*** }} \\
(0.023)\end{array}$ & $\begin{array}{l}-0.025 \\
(0.022)\end{array}$ & $\begin{array}{l}-0.019 \\
(0.022)\end{array}$ \\
\hline $\begin{array}{l}\text { Grade } 8 \\
\text { interaction }\end{array}$ & $\begin{array}{l}-0.028 \\
(0.026)\end{array}$ & $\begin{array}{l}-0.029 \\
(0.026)\end{array}$ & $\begin{array}{l}-0.030 \\
(0.026)\end{array}$ & $\begin{array}{l}-0.025 \\
(0.026)\end{array}$ \\
\hline
\end{tabular}

${ }^{1}$ Robust standard errors are presented in parentheses. ${ }^{* * *},{ }^{* * *}$ indicate statistical significance at $10 \%, 5 \%$ and $1 \%$ levels, respectively.

${ }^{2}$ The covariates include the age and a dummy indicator of free school lunch status for each student, as well as school characteristics, namely the proportions of female students and minority students. 
Table 5. 2SLS BMI Impact Estimates of Middle School Transition by Gender and Minority Status $^{1,2}$

\begin{tabular}{|c|c|c|c|c|c|c|}
\hline & \multicolumn{3}{|c|}{ Non-minority students } & \multicolumn{3}{|c|}{ Minority students } \\
\hline & $\begin{array}{c}\text { All } \\
(\mathrm{n}=43,475)\end{array}$ & $\begin{array}{c}\text { Boys } \\
(\mathrm{n}=21,645)\end{array}$ & $\begin{array}{c}\text { Girls } \\
(\mathrm{n}=21,830)\end{array}$ & $\begin{array}{c}\text { All } \\
(n=20,475)\end{array}$ & $\begin{array}{c}\text { Boys } \\
(\mathrm{n}=10,930)\end{array}$ & $\begin{array}{c}\text { Girls } \\
(\mathrm{n}=9,545)\end{array}$ \\
\hline \multicolumn{7}{|c|}{ Transition in grade 5} \\
\hline $\begin{array}{l}\text { Grade } 4 \\
\text { interaction }\end{array}$ & $\begin{array}{c}0.004 \\
(0.017)\end{array}$ & $\begin{array}{c}0.003 \\
(0.025)\end{array}$ & $\begin{array}{c}0.006 \\
(0.024)\end{array}$ & $\begin{array}{c}0.036 \\
(0.045)\end{array}$ & $\begin{array}{l}-0.011 \\
(0.038)\end{array}$ & $\begin{array}{c}0.073 \\
(0.055)\end{array}$ \\
\hline $\begin{array}{l}\text { Grade } 5 \\
\text { interaction }\end{array}$ & $\begin{array}{c}-0.005 \\
(0.016)\end{array}$ & $\begin{array}{l}-0.001 \\
(0.023)\end{array}$ & $\begin{array}{l}-0.007 \\
(0.023)\end{array}$ & $\begin{array}{l}-0.003 \\
(0.014)\end{array}$ & $\begin{array}{c}0.039 \\
(0.044)\end{array}$ & $\begin{array}{c}0.034 \\
(0.050)\end{array}$ \\
\hline $\begin{array}{l}\text { Grade } 6 \\
\text { interaction }\end{array}$ & $\begin{array}{c}-0.013 \\
(0.017)\end{array}$ & $\begin{array}{l}-0.008 \\
(0.025)\end{array}$ & $\begin{array}{l}-0.018 \\
(0.024)\end{array}$ & $\begin{array}{c}0.039 \\
(0.035)\end{array}$ & $\begin{array}{c}0.020 \\
(0.033)\end{array}$ & $\begin{array}{c}0.069 \\
(0.058)\end{array}$ \\
\hline $\begin{array}{l}\text { Grade } 8 \\
\text { interaction }\end{array}$ & $\begin{array}{c}-0.028 \\
(0.020)\end{array}$ & $\begin{array}{l}-0.034 \\
(0.029)\end{array}$ & $\begin{array}{l}-0.026 \\
(0.029)\end{array}$ & $\begin{array}{c}0.005 \\
(0.046)\end{array}$ & $\begin{array}{c}0.027 \\
(0.052)\end{array}$ & $\begin{array}{l}-0.011 \\
(0.023)\end{array}$ \\
\hline \multicolumn{7}{|c|}{ Transition in grade 6} \\
\hline $\begin{array}{l}\text { Grade } 4 \\
\text { interaction }\end{array}$ & $\begin{array}{c}-0.009 \\
(0.019)\end{array}$ & $\begin{array}{c}0.005 \\
(0.027)\end{array}$ & $\begin{array}{l}-0.023 \\
(0.026)\end{array}$ & $\begin{array}{c}0.049 \\
(0.041)\end{array}$ & $\begin{array}{c}0.040 \\
(0.053)\end{array}$ & $\begin{array}{c}0.066 \\
(0.049)\end{array}$ \\
\hline $\begin{array}{l}\text { Grade } 5 \\
\text { interaction }\end{array}$ & $\begin{array}{c}-0.025 \\
(0.018)\end{array}$ & $\begin{array}{l}-0.030 \\
(0.026)\end{array}$ & $\begin{array}{l}-0.018 \\
(0.025)\end{array}$ & $\begin{array}{c}0.067 \\
(0.055)\end{array}$ & $\begin{array}{c}0.062 \\
(0.090)\end{array}$ & $\begin{array}{c}0.059 \\
(0.042)\end{array}$ \\
\hline $\begin{array}{l}\text { Grade } 6 \\
\text { interaction }\end{array}$ & $\begin{array}{c}-0.073^{* * *} \\
(0.019)\end{array}$ & $\begin{array}{c}-0.091^{* * *} \\
(0.028)\end{array}$ & $\begin{array}{c}-0.055^{* *} \\
(0.026)\end{array}$ & $\begin{array}{c}0.022 \\
(0.040)\end{array}$ & $\begin{array}{c}-0.054^{*} \\
(0.029)\end{array}$ & $\begin{array}{c}0.021 \\
(0.020)\end{array}$ \\
\hline $\begin{array}{l}\text { Grade } 8 \\
\text { interaction }\end{array}$ & $\begin{array}{c}-0.075^{* * *} \\
(0.022)\end{array}$ & $\begin{array}{c}-0.096^{* * *} \\
(0.033)\end{array}$ & $\begin{array}{l}-0.057^{*} \\
(0.030)\end{array}$ & $\begin{array}{c}0.017 \\
(0.033)\end{array}$ & $\begin{array}{l}-0.015 \\
(0.062)\end{array}$ & $\begin{array}{c}0.033 \\
(0.036)\end{array}$ \\
\hline
\end{tabular}

${ }^{1}$ Covariates are included in the estimation, namely the age and a dummy indicator of free school lunch status for each student, as well as school characteristics, namely the proportions of female students and minority students.

${ }^{2}$ Robust standard errors are presented in parentheses. ${ }^{*},{ }^{* *},{ }^{* * *}$ indicate statistical significance at $10 \%, 5 \%$ and $1 \%$ levels, respectively. 


\section{Appendix:}

This appendix presents the first-stage estimates from the full sample, as well as the estimates for multiple robustness checks mentioned in the article but not formally reported therein. Table A.1 presents the first-stage regression estimates. Table A.2 shows the 2SLS BMI impact estimates for non-movers only. Table A.3 shows the 2SLS BMI impact estimates for one-time switchers only (i.e. those who switched only once from elementary school to middle school). Table A.4 shows the 2SLS BMI impact estimates with school district fixed effects. Table A.5 shows the 2SLS BMI impact estimates using an expanded sample that includes less common school types (mainly K-3, 3-5 and 3-6 schools). 
Table A.1. Coefficient Estimates of Instruments in First-Stage Regressions ${ }^{1}$

\begin{tabular}{|l|c|c|}
\hline & Transition in grade 5 & Transition in grade 6 \\
\hline Instrument for grade 5 transition & $\begin{array}{c}0.818^{* * *} \\
(0.006)\end{array}$ & \\
\hline Instrument for grade 6 transition & & $\begin{array}{c}0.685^{* * *} \\
(0.007)\end{array}$ \\
\hline Constant & & $0.115^{* * *}$ \\
& $(0.003)$ & $(0.005)$ \\
\hline$R^{2}$ & 0.729 & 0.689 \\
\hline F-statistic & $2907.17^{* * * *}$ & $2215.88^{* * *}$ \\
\hline Number of observations & 63,950 & 63,950 \\
\hline
\end{tabular}

1 Robust standard errors of coefficient estimates are presented in parentheses. ${ }^{*},{ }^{* * * * *},{ }^{*}$ indicate statistical significance at $10 \%, 5 \%$ and $1 \%$ levels, respectively. Covariate coefficients are not reported here. 
Table A.2. 2SLS BMI Impact Estimates of Middle School Transition on Student Sub-Samples:

$$
\text { Non-Movers Only }{ }^{1,2}
$$

\begin{tabular}{|c|c|c|c|c|c|c|}
\hline & \multicolumn{3}{|c|}{ Non-minority students } & \multicolumn{3}{|c|}{ Minority students } \\
\hline & $\begin{array}{c}\text { All } \\
(\mathrm{n}=24,515)\end{array}$ & $\begin{array}{c}\text { Boys } \\
(n=12,235)\end{array}$ & $\begin{array}{c}\text { Girls } \\
(\mathrm{n}=12,280)\end{array}$ & $\begin{array}{c}\text { All } \\
(\mathrm{n}=10,960)\end{array}$ & $\begin{array}{c}\text { Boys } \\
(n=5,950)\end{array}$ & $\underset{(n=5,010)}{\text { Girls }}$ \\
\hline \multicolumn{7}{|c|}{ Transition in grade 5} \\
\hline $\begin{array}{l}\text { Grade } 4 \\
\text { interaction }\end{array}$ & $\begin{array}{c}0.004 \\
(0.014)\end{array}$ & $\begin{array}{c}0.005 \\
(0.021)\end{array}$ & $\begin{array}{c}0.004 \\
(0.019)\end{array}$ & $\begin{array}{c}0.027 \\
(0.020)\end{array}$ & $\begin{array}{c}0.003 \\
(0.021)\end{array}$ & $\begin{array}{c}0.037 \\
(0.022)\end{array}$ \\
\hline $\begin{array}{l}\text { Grade } 5 \\
\text { interaction }\end{array}$ & $\begin{array}{c}-0.003 \\
(0.017)\end{array}$ & $\begin{array}{l}-0.001 \\
(0.024)\end{array}$ & $\begin{array}{l}-0.003 \\
(0.027)\end{array}$ & $\begin{array}{c}0.013 \\
(0.010)\end{array}$ & $\begin{array}{c}0.024 \\
(0.059)\end{array}$ & $\begin{array}{c}0.042 \\
(0.043)\end{array}$ \\
\hline $\begin{array}{l}\text { Grade } 6 \\
\text { interaction }\end{array}$ & $\begin{array}{c}-0.008 \\
(0.017)\end{array}$ & $\begin{array}{l}-0.005 \\
(0.025)\end{array}$ & $\begin{array}{l}-0.011 \\
(0.019)\end{array}$ & $\begin{array}{c}0.035 \\
(0.026)\end{array}$ & $\begin{array}{c}0.017 \\
(0.038)\end{array}$ & $\begin{array}{c}0.057 \\
(0.046)\end{array}$ \\
\hline $\begin{array}{l}\text { Grade } 8 \\
\text { interaction }\end{array}$ & $\begin{array}{c}-0.026 \\
(0.018)\end{array}$ & $\begin{array}{l}-0.031 \\
(0.030)\end{array}$ & $\begin{array}{l}-0.023 \\
(0.025)\end{array}$ & $\begin{array}{c}0.012 \\
(0.022)\end{array}$ & $\begin{array}{c}0.016 \\
(0.025)\end{array}$ & $\begin{array}{c}0.010 \\
(0.028)\end{array}$ \\
\hline \multicolumn{7}{|c|}{ Transition in grade 6} \\
\hline $\begin{array}{l}\text { Grade } 4 \\
\text { interaction }\end{array}$ & $\begin{array}{c}-0.007 \\
(0.018)\end{array}$ & $\begin{array}{c}0.002 \\
(0.028)\end{array}$ & $\begin{array}{l}-0.014 \\
(0.028)\end{array}$ & $\begin{array}{c}0.058 \\
(0.044)\end{array}$ & $\begin{array}{c}0.047 \\
(0.052)\end{array}$ & $\begin{array}{c}0.061 \\
(0.064)\end{array}$ \\
\hline $\begin{array}{l}\text { Grade } 5 \\
\text { interaction }\end{array}$ & $\begin{array}{l}-0.021 \\
(0.021)\end{array}$ & $\begin{array}{l}-0.032 \\
(0.027)\end{array}$ & $\begin{array}{l}-0.006 \\
(0.027)\end{array}$ & $\begin{array}{l}0.063^{*} \\
(0.035)\end{array}$ & $\begin{array}{c}0.050 \\
(0.077)\end{array}$ & $\begin{array}{c}0.073 \\
(0.056)\end{array}$ \\
\hline $\begin{array}{l}\text { Grade } 6 \\
\text { interaction }\end{array}$ & $\begin{array}{c}-0.063^{* * *} \\
(0.022)\end{array}$ & $\begin{array}{c}-0.088^{* * *} \\
(0.029)\end{array}$ & $\begin{array}{c}-0.037^{* *} \\
(0.016)\end{array}$ & $\begin{array}{c}0.016 \\
(0.034)\end{array}$ & $\begin{array}{l}-0.055^{*} \\
(0.031)\end{array}$ & $\begin{array}{c}0.036 \\
(0.028)\end{array}$ \\
\hline $\begin{array}{l}\text { Grade } 8 \\
\text { interaction }\end{array}$ & $\begin{array}{c}-0.068^{* * *} \\
(0.024)\end{array}$ & $\begin{array}{c}-0.092^{* * *} \\
(0.035)\end{array}$ & $\begin{array}{c}-0.044 \text { * } \\
(0.026)\end{array}$ & $\begin{array}{c}0.027 \\
(0.023)\end{array}$ & $\begin{array}{c}0.012 \\
(0.034)\end{array}$ & $\begin{array}{c}0.033 \\
(0.032)\end{array}$ \\
\hline
\end{tabular}

${ }^{1}$ Covariates are included in the estimation, namely the age and a dummy indicator of free school lunch status for each student, as well as school characteristics, namely the proportions of female students and minority students.

${ }^{2}$ Robust standard errors are presented in parentheses. ${ }^{*},{ }^{* *},{ }^{* * *}$ indicate statistical significance at $10 \%, 5 \%$ and $1 \%$ levels, respectively. 
Table A.3. 2SLS BMI Impact Estimates of Middle School Transition on Student Sub-Samples: One-Time Switchers Only ${ }^{1,2}$

\begin{tabular}{|c|c|c|c|c|c|c|}
\hline & \multicolumn{3}{|c|}{ Non-minority students } & \multicolumn{3}{|c|}{ Minority students } \\
\hline & $\begin{array}{c}\text { All } \\
(\mathrm{n}=18,670)\end{array}$ & $\begin{array}{c}\text { Boys } \\
(n=9,125)\end{array}$ & $\begin{array}{c}\text { Girls } \\
(\mathrm{n}=9,545)\end{array}$ & $\begin{array}{c}\text { All } \\
(\mathrm{n}=7,055)\end{array}$ & $\begin{array}{c}\text { Boys } \\
(n=3,730)\end{array}$ & $\begin{array}{c}\text { Girls } \\
(n=3,325)\end{array}$ \\
\hline \multicolumn{7}{|c|}{ Transition in grade 5} \\
\hline $\begin{array}{l}\text { Grade } 4 \\
\text { interaction }\end{array}$ & $\begin{array}{c}0.014 \\
(0.024)\end{array}$ & $\begin{array}{c}0.017 \\
(0.033)\end{array}$ & $\begin{array}{c}0.009 \\
(0.034)\end{array}$ & $\begin{array}{c}0.030 \\
(0.021)\end{array}$ & $\begin{array}{c}0.026 \\
(0.033)\end{array}$ & $\begin{array}{c}0.034 \\
(0.024)\end{array}$ \\
\hline $\begin{array}{l}\text { Grade } 5 \\
\text { interaction }\end{array}$ & $\begin{array}{c}0.006 \\
(0.022)\end{array}$ & $\begin{array}{c}0.016 \\
(0.031)\end{array}$ & $\begin{array}{l}-0.006 \\
(0.031)\end{array}$ & $\begin{array}{l}-0.008 \\
(0.055)\end{array}$ & $\begin{array}{c}0.016 \\
(0.094)\end{array}$ & $\begin{array}{l}-0.021 \\
(0.072)\end{array}$ \\
\hline $\begin{array}{l}\text { Grade } 6 \\
\text { interaction }\end{array}$ & $\begin{array}{c}-0.004 \\
(0.024)\end{array}$ & $\begin{array}{c}0.022 \\
(0.033)\end{array}$ & $\begin{array}{c}-0.032 \\
(0.034)\end{array}$ & $\begin{array}{c}0.022 \\
(0.029)\end{array}$ & $\begin{array}{c}0.013 \\
(0.036)\end{array}$ & $\begin{array}{c}0.027 \\
(0.021)\end{array}$ \\
\hline $\begin{array}{l}\text { Grade } 8 \\
\text { interaction }\end{array}$ & $\begin{array}{c}0.017 \\
(0.027)\end{array}$ & $\begin{array}{c}0.023 \\
(0.037)\end{array}$ & $\begin{array}{l}-0.009 \\
(0.039)\end{array}$ & $\begin{array}{c}0.016 \\
(0.025)\end{array}$ & $\begin{array}{c}0.009 \\
(0.033)\end{array}$ & $\begin{array}{c}0.017 \\
(0.031)\end{array}$ \\
\hline \multicolumn{7}{|c|}{ Transition in grade 6} \\
\hline $\begin{array}{l}\text { Grade } 4 \\
\text { interaction }\end{array}$ & $\begin{array}{c}0.024 \\
(0.018)\end{array}$ & $\begin{array}{c}0.002 \\
(0.028)\end{array}$ & $\begin{array}{c}-0.014 \\
(0.034)\end{array}$ & $\begin{array}{c}0.048 \\
(0.046)\end{array}$ & $\begin{array}{c}0.031 \\
(0.052)\end{array}$ & $\begin{array}{c}0.076 \\
(0.069)\end{array}$ \\
\hline $\begin{array}{l}\text { Grade } 5 \\
\text { interaction }\end{array}$ & $\begin{array}{c}0.026 \\
(0.018)\end{array}$ & $\begin{array}{c}0.030 \\
(0.026)\end{array}$ & $\begin{array}{c}0.018 \\
(0.024)\end{array}$ & $\begin{array}{c}0.046 \\
(0.061)\end{array}$ & $\begin{array}{c}0.021 \\
(0.073)\end{array}$ & $\begin{array}{c}0.068 \\
(0.070)\end{array}$ \\
\hline $\begin{array}{l}\text { Grade } 6 \\
\text { interaction }\end{array}$ & $\begin{array}{c}-0.053^{* * *} \\
(0.019)\end{array}$ & $\begin{array}{c}-0.077^{\text {*** }} \\
(0.027)\end{array}$ & $\begin{array}{c}-0.044^{* *} \\
(0.020)\end{array}$ & $\begin{array}{l}-0.017 \\
(0.055)\end{array}$ & $\begin{array}{l}-0.045 \\
(0.113)\end{array}$ & $\begin{array}{c}0.022 \\
(0.070)\end{array}$ \\
\hline $\begin{array}{l}\text { Grade } 8 \\
\text { interaction }\end{array}$ & $\begin{array}{c}-0.062^{* * *} \\
(0.019)\end{array}$ & $\begin{array}{c}-0.081^{* * *} \\
(0.028)\end{array}$ & $\begin{array}{c}-0.043^{* *} \\
(0.022)\end{array}$ & $\begin{array}{c}0.031 \\
(0.072)\end{array}$ & $\begin{array}{c}0.018 \\
(0.084)\end{array}$ & $\begin{array}{c}0.045 \\
(0.098)\end{array}$ \\
\hline
\end{tabular}

${ }^{1}$ Covariates are included in the estimation, namely the age and a dummy indicator of free school lunch status for each student, as well as school characteristics, namely the proportions of female students and minority students.

${ }^{2}$ Robust standard errors are presented in parentheses. ${ }^{*},{ }^{* *},{ }^{* * *}$ indicate statistical significance at $10 \%, 5 \%$ and $1 \%$ levels, respectively. 
Table A.4. 2SLS BMI Impact Estimates of Middle School Transition on Student Sub-Samples:

With School District Fixed Effects ${ }^{1,2}$

\begin{tabular}{|c|c|c|c|c|c|c|}
\hline & \multicolumn{3}{|c|}{ Non-minority students } & \multicolumn{3}{|c|}{ Minority students } \\
\hline & $\begin{array}{c}\text { All } \\
(\mathrm{n}=43,475)\end{array}$ & $\begin{array}{c}\text { Boys } \\
(\mathrm{n}=21,645)\end{array}$ & $\begin{array}{c}\text { Girls } \\
(\mathrm{n}=21,830)\end{array}$ & $\begin{array}{c}\text { All } \\
(\mathrm{n}=20,475)\end{array}$ & $\begin{array}{c}\text { Boys } \\
(\mathrm{n}=10,930)\end{array}$ & $\underset{(n=9,545)}{\text { Girls }}$ \\
\hline \multicolumn{7}{|c|}{ Transition in grade 5} \\
\hline $\begin{array}{l}\text { Grade } 4 \\
\text { interaction }\end{array}$ & $\begin{array}{c}0.002 \\
(0.018)\end{array}$ & $\begin{array}{c}0.001 \\
(0.022)\end{array}$ & $\begin{array}{c}0.006 \\
(0.027)\end{array}$ & $\begin{array}{c}0.033 \\
(0.062)\end{array}$ & $\begin{array}{l}-0.040 \\
(0.065)\end{array}$ & $\begin{array}{c}0.104 \\
(0.122)\end{array}$ \\
\hline $\begin{array}{l}\text { Grade } 5 \\
\text { interaction }\end{array}$ & $\begin{array}{c}-0.005 \\
(0.019)\end{array}$ & $\begin{array}{l}-0.004 \\
(0.025)\end{array}$ & $\begin{array}{l}-0.008 \\
(0.026)\end{array}$ & $\begin{array}{c}-0.007 \\
(0.055)\end{array}$ & $\begin{array}{c}0.053 \\
(0.093)\end{array}$ & $\begin{array}{l}-0.052 \\
(0.067)\end{array}$ \\
\hline $\begin{array}{l}\text { Grade } 6 \\
\text { interaction }\end{array}$ & $\begin{array}{l}-0.010 \\
(0.012)\end{array}$ & $\begin{array}{l}-0.025 \\
(0.029)\end{array}$ & $\begin{array}{c}0.014 \\
(0.026)\end{array}$ & $\begin{array}{c}0.004 \\
(0.009)\end{array}$ & $\begin{array}{l}-0.036 \\
(0.025)\end{array}$ & $\begin{array}{c}0.021 \\
(0.014)\end{array}$ \\
\hline $\begin{array}{l}\text { Grade } 8 \\
\text { interaction }\end{array}$ & $\begin{array}{l}-0.019 \\
(0.022)\end{array}$ & $\begin{array}{l}-0.026 \\
(0.025)\end{array}$ & $\begin{array}{l}-0.014 \\
(0.023)\end{array}$ & $\begin{array}{c}0.067 \\
(0.088)\end{array}$ & $\begin{array}{c}0.016 \\
(0.068)\end{array}$ & $\begin{array}{c}0.081 \\
(0.084)\end{array}$ \\
\hline \multicolumn{7}{|c|}{ Transition in grade 6} \\
\hline $\begin{array}{l}\text { Grade } 4 \\
\text { interaction }\end{array}$ & $\begin{array}{c}-0.006 \\
(0.020)\end{array}$ & $\begin{array}{c}0.005 \\
(0.023)\end{array}$ & $\begin{array}{c}-0.018 \\
(0.036)\end{array}$ & $\begin{array}{c}0.053 \\
(0.040)\end{array}$ & $\begin{array}{c}0.021 \\
(0.053)\end{array}$ & $\begin{array}{c}0.087 \\
(0.061)\end{array}$ \\
\hline $\begin{array}{l}\text { Grade } 5 \\
\text { interaction }\end{array}$ & $\begin{array}{l}-0.024 \\
(0.017)\end{array}$ & $\begin{array}{l}-0.029 \\
(0.023)\end{array}$ & $\begin{array}{l}-0.016 \\
(0.028)\end{array}$ & $\begin{array}{c}0.079 \\
(0.064)\end{array}$ & $\begin{array}{c}0.053 \\
(0.074)\end{array}$ & $\begin{array}{c}0.098 \\
(0.067)\end{array}$ \\
\hline $\begin{array}{l}\text { Grade } 6 \\
\text { interaction }\end{array}$ & $\begin{array}{c}-0.066^{* * *} \\
(0.023)\end{array}$ & $\begin{array}{c}-0.087^{* * *} \\
(0.029)\end{array}$ & $\begin{array}{c}-0.055^{* *} \\
(0.028)\end{array}$ & $\begin{array}{c}0.015 \\
(0.046)\end{array}$ & $\begin{array}{l}-0.081 \\
(0.055)\end{array}$ & $\begin{array}{c}0.102 \\
(0.083)\end{array}$ \\
\hline $\begin{array}{l}\text { Grade } 8 \\
\text { interaction }\end{array}$ & $\begin{array}{c}-0.070^{* * * *} \\
(0.015)\end{array}$ & $\begin{array}{c}-0.078^{* *} \\
(0.034)\end{array}$ & $\begin{array}{c}-0.054^{* *} \\
(0.026)\end{array}$ & $\begin{array}{c}0.044 \\
(0.049)\end{array}$ & $\begin{array}{c}0.027 \\
(0.066)\end{array}$ & $\begin{array}{c}0.068 \\
(0.060)\end{array}$ \\
\hline
\end{tabular}

${ }^{1}$ Covariates are included in the estimation, namely the age and a dummy indicator of free school lunch status for each student, as well as school characteristics, namely the proportions of female students and minority students.

${ }^{2}$ Robust standard errors are presented in parentheses. ${ }^{*},{ }^{* *},{ }^{* * *}$ indicate statistical significance at $10 \%, 5 \%$ and $1 \%$ levels, respectively. 
Table A.5. 2SLS BMI Impact Estimates of Middle School Transition on Student Sub-Samples: With Less Common School Types ${ }^{1,2}$

\begin{tabular}{|c|c|c|c|c|c|c|}
\hline & \multicolumn{3}{|c|}{ Non-minority students } & \multicolumn{3}{|c|}{ Minority students } \\
\hline & $\begin{array}{c}\text { All } \\
(\mathrm{n}=62,165)\end{array}$ & $\begin{array}{c}\text { Boys } \\
(n=31,585)\end{array}$ & $\begin{array}{c}\text { Girls } \\
(\mathrm{n}=30,580)\end{array}$ & $\begin{array}{c}\text { All } \\
(\mathrm{n}=26,330)\end{array}$ & $\begin{array}{c}\text { Boys } \\
(n=13,455)\end{array}$ & $\begin{array}{c}\text { Girls } \\
(\mathrm{n}=12,875)\end{array}$ \\
\hline \multicolumn{7}{|c|}{ Transition in grade 5} \\
\hline $\begin{array}{l}\text { Grade } 4 \\
\text { interaction }\end{array}$ & $\begin{array}{c}0.004 \\
(0.015)\end{array}$ & $\begin{array}{c}0.004 \\
(0.011)\end{array}$ & $\begin{array}{c}0.009 \\
(0.018)\end{array}$ & $\begin{array}{c}0.026 \\
(0.055)\end{array}$ & $\begin{array}{l}-0.037 \\
(0.061)\end{array}$ & $\begin{array}{c}0.078 \\
(0.111)\end{array}$ \\
\hline $\begin{array}{l}\text { Grade } 5 \\
\text { interaction }\end{array}$ & $\begin{array}{c}-0.011 \\
(0.006)\end{array}$ & $\begin{array}{l}-0.016 \\
(0.012)\end{array}$ & $\begin{array}{l}-0.005 \\
(0.008)\end{array}$ & $\begin{array}{l}-0.018 \\
(0.012)\end{array}$ & $\begin{array}{l}-0.014 \\
(0.074)\end{array}$ & $\begin{array}{l}-0.027 \\
(0.039)\end{array}$ \\
\hline $\begin{array}{l}\text { Grade } 6 \\
\text { interaction }\end{array}$ & $\begin{array}{c}0.011 \\
(0.013)\end{array}$ & $\begin{array}{l}-0.003 \\
(0.007)\end{array}$ & $\begin{array}{c}0.016 \\
(0.023)\end{array}$ & $\begin{array}{c}-0.002 \\
(0.005)\end{array}$ & $\begin{array}{l}-0.012 \\
(0.016)\end{array}$ & $\begin{array}{c}0.009 \\
(0.007)\end{array}$ \\
\hline $\begin{array}{l}\text { Grade } 8 \\
\text { interaction }\end{array}$ & $\begin{array}{c}0.025 \\
(0.019)\end{array}$ & $\begin{array}{c}0.001 \\
(0.029)\end{array}$ & $\begin{array}{c}0.044 \\
(0.037)\end{array}$ & $\begin{array}{c}0.043 \\
(0.048)\end{array}$ & $\begin{array}{c}0.021 \\
(0.050)\end{array}$ & $\begin{array}{c}0.076 \\
(0.062)\end{array}$ \\
\hline \multicolumn{7}{|c|}{ Transition in grade 6} \\
\hline $\begin{array}{l}\text { Grade } 4 \\
\text { interaction }\end{array}$ & $\begin{array}{c}0.005 \\
(0.011)\end{array}$ & $\begin{array}{c}0.027 \\
(0.023)\end{array}$ & $\begin{array}{l}-0.017 \\
(0.030)\end{array}$ & $\begin{array}{c}0.036 \\
(0.044)\end{array}$ & $\begin{array}{c}0.021 \\
(0.053)\end{array}$ & $\begin{array}{c}0.067 \\
(0.051)\end{array}$ \\
\hline $\begin{array}{l}\text { Grade } 5 \\
\text { interaction }\end{array}$ & $\begin{array}{l}-0.021 \\
(0.015)\end{array}$ & $\begin{array}{l}-0.022 \\
(0.024)\end{array}$ & $\begin{array}{l}-0.018 \\
(0.017)\end{array}$ & $\begin{array}{c}0.049 \\
(0.031)\end{array}$ & $\begin{array}{c}0.053 \\
(0.042)\end{array}$ & $\begin{array}{c}0.044 \\
(0.054)\end{array}$ \\
\hline $\begin{array}{l}\text { Grade } 6 \\
\text { interaction }\end{array}$ & $\begin{array}{c}-0.063^{* * *} \\
(0.017)\end{array}$ & $\begin{array}{c}-0.080^{* * *} \\
(0.024)\end{array}$ & $\begin{array}{c}-0.047^{* *} \\
(0.019)\end{array}$ & $\begin{array}{c}0.015 \\
(0.023)\end{array}$ & $\begin{array}{l}-0.058 \\
(0.045)\end{array}$ & $\begin{array}{c}0.069 \\
(0.072)\end{array}$ \\
\hline $\begin{array}{l}\text { Grade } 8 \\
\text { interaction }\end{array}$ & $\begin{array}{c}-0.058^{* * *} \\
(0.014)\end{array}$ & $\begin{array}{c}-0.067^{* * *} \\
(0.022)\end{array}$ & $\begin{array}{c}-0.037^{* *} \\
(0.016)\end{array}$ & $\begin{array}{c}0.033 \\
(0.039)\end{array}$ & $\begin{array}{c}0.027 \\
(0.076)\end{array}$ & $\begin{array}{c}0.038 \\
(0.081)\end{array}$ \\
\hline
\end{tabular}

${ }^{1}$ Covariates are included in the estimation, namely the age and a dummy indicator of free school lunch status for each student, as well as school characteristics, namely the proportions of female students and minority students.

${ }^{2}$ Robust standard errors are presented in parentheses. ${ }^{*},{ }^{* *},{ }^{* * *}$ indicate statistical significance at $10 \%, 5 \%$ and $1 \%$ levels, respective. 